\title{
AN INSIGHT INTO THE BRYOPHYTE FLORA OF THE IBAR GORGE AND ITS SURROUNDINGS (CENTRAL AND SW SERBIA)
}

\author{
B. Papp ${ }^{1}$, E. Szurdoki ${ }^{1}$, J. Pantović ${ }^{2}$ and M. Sabovljević ${ }^{2}$ \\ ${ }^{1}$ Department of Botany, Hungarian Natural History Museum \\ H-1431, Budapest, Pf. 137, Hungary; E-mail: pappbea@bot.nhmus.hu \\ ${ }^{2}$ Institute of Botany and Botanical Garden, Faculty of Biology, University of Belgrade \\ 11000 Belgrade, Serbia
}

(Received 5 May, 2016; Accepted 15 July, 2016)

\begin{abstract}
A total of 126 bryophyte taxa (12 liverworts and 114 mosses) were collected in the Ibar gorge and its surroundings. The climate of the gorge receives Mediterranean influence, hence almost one fourth part of the species found are Mediterranean, sub-Mediterranean, or sub-Atlantic elements. Several rare species in Serbia and in the Balkans can be found in the territory (e.g. Bryum gemmiferum, Dialytrichia mucronata, Didymodon nicholsonii, Grimmia lisae, Gymnostomum viridulum, Hygroamblystegium humile, Orthotrichum obtusifolium, Syntrichia latifolia). One species (Buxbaumia viridis) is included in the Bern Convention and the European Union Habitats and Species Directives. The Ibar gorge maintains a unique bryophyte assemblage due to the serpentine bedrock and continental, Mediterranean climatic influence, which are the main characteristics of the region.
\end{abstract}

Key words: European red-listed species, liverworts, mosses, rare bryophytes, the Balkans

\section{INTRODUCTION}

After the decades of the neglect of bryophyte investigation in Serbia, the last 15 years brought a lot of novelties to the national flora. New species records and the confirmation of old and forgotten bryophyte taxa continuously appear with every new investigation conducted in some area of Serbia. Sabovljević and Stevanović (1999) cited 423 moss species for Serbia, while the subsequent updated checklists (Sabovljević et al. 2008: 555 species and Ros et al. 2013: 575) show significant growth in the number of species. Similarly, Sabovljević (2000) cited 81 liverwort species for Serbia, and Sabovljević and Natcheva (2006) and Ros et al. (2007) cited 118 and 120 liverworts, respec- 
tively. Apart from the list of species already published in these references, additional new records can be mentioned, e.g. more recently in Papp et al. 2014c, d, e, 2015).

The present study brings an overview of the bryophyte species recorded in previously not investigated area of Ibarski kraj, in the region of Central and SW Serbia.

\section{MATERIAL AND METHODS}

\section{Study area}

The river Ibar flows to north in the area of SW-Central Serbia and forms its lower part through ravines and gorges before enters to the river Western Morava (Zapadna Morava). This part of the lower river flow is surrounded by hills, slopes and also the Stolovi Mts. There, in its lower course the Ibar receives its major tributaries: Raška, Studenica, Jošanica and Lopatnica rivers, and became rather powerful river. In this section, the river has carved the 40 $\mathrm{km}$ long and $550 \mathrm{~m}$ deep Ibar gorge. The whole area is ca $110 \mathrm{~km}$ long and 15$20 \mathrm{~km}$ wide, and known as Ibarski kraj (Marković 1990). The lower course of Ibar is divided into several valleys among the mountains of Golija, Čemerno, Troglav, Kopaonik, Željin and Stolovi.

The Stolovi Mts is one of the mountains that stretches along the Ibar gorge. It is ca $12 \mathrm{~km}$ long. The highest peak is Usovica $(1,375 \mathrm{~m})$. The southern slopes are quite naked or covered by rocky grasslands. The northern slopes are overgrown by different forests mainly predominated by thermophilous types.

The region of the Ibar gorge and its surroundings (including neighbouring mountains) is geologically mixed and complex with various types of rocks; serpentinite and serpentinised peridotite, basic and ultrabasic igneous rocks, limestone from the Triassic; flysch, dacite-andesite volcanic formations and sediments from the Tertiary and Quaternary (Mladenović 2010). In the Stolovi Mts mainly acidic soils are frequent, naturally overloaded with magnesium and chromium. However, the main characteristics of the region are ultramaphic rocks and soils.

The climate has continental and Mediterranean influence with cold winters and hot summers and long summer drought period.

\section{Methods}

Our fieldwork was carried out at 11 localities (Fig. 1) in April 2013 (see details below). All main habitat types, such as river bank, rock formations, grasslands and forests were investigated, and bryophytes collected from different substrates (soil, exposed and shaded rocks, tree bark, and decaying wood). 
Voucher specimens are deposited in the collections of the Hungarian Natural History Museum, Budapest (BP) and Belgrade University Herbarium (BEOU). Nomenclature follows Grolle and Long (2000) for liverworts and Smith (2004) and Hill et al. (2006) for mosses. European distribution of the species is given according to Düll $(1983,1984,1985)$.

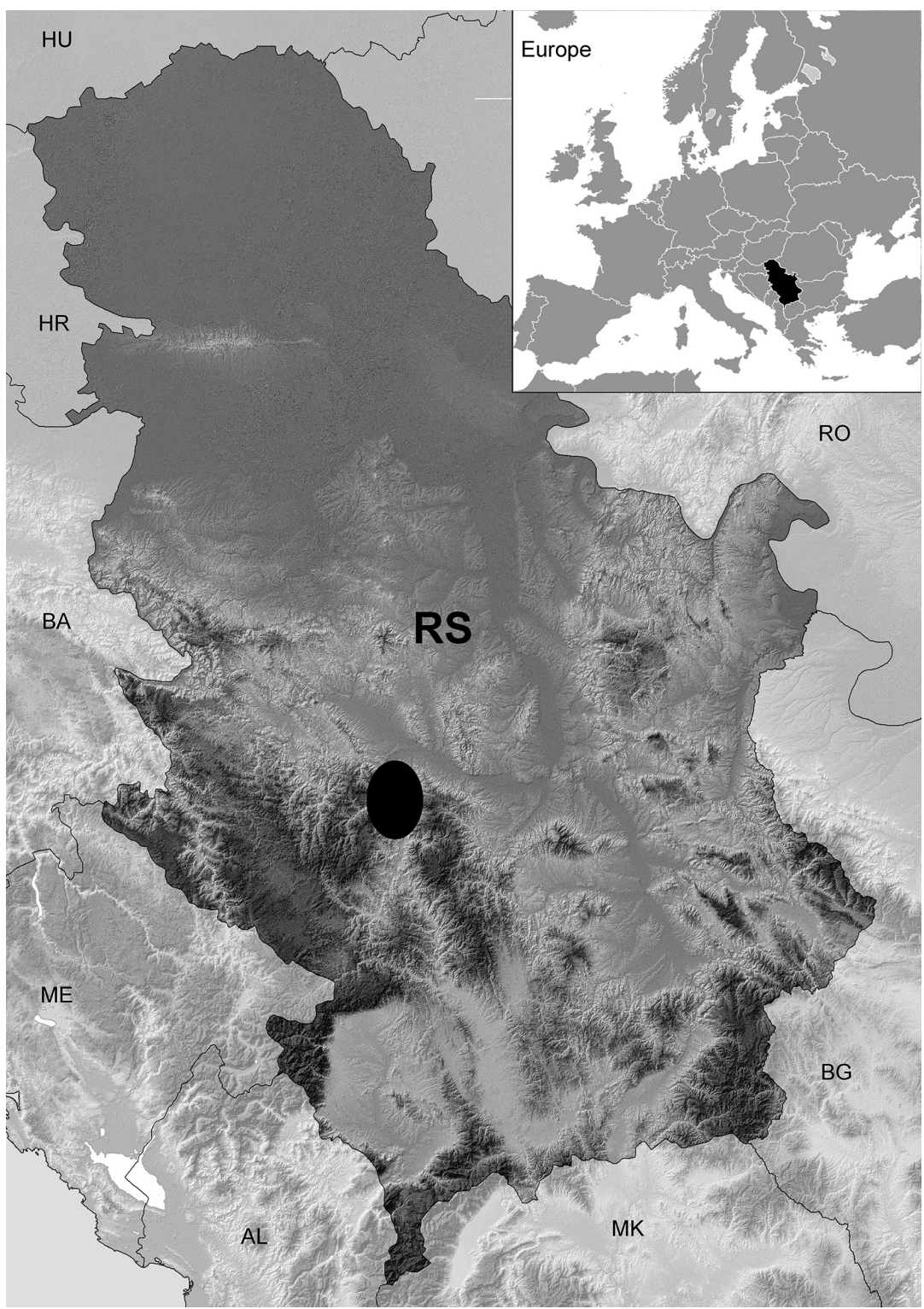

Fig. 1. Location of the studied area 


\section{Locality details}

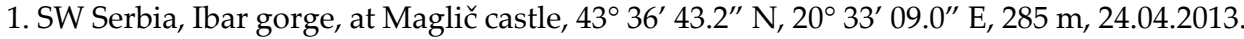

2. Central Serbia, Stolovi Mts, by town of Kraljevo, 43 37' 54.2" N, $20^{\circ} 37^{\prime} 27.1^{\prime \prime}$ E, $780 \mathrm{~m}$, 25.04.2013.

3. Central Serbia, Stolovi Mts, by town of Kraljevo, towards Usovica peak, in Abieto-Fagetum, $43^{\circ} 37^{\prime} 39.9^{\prime \prime} \mathrm{N}, 20^{\circ} 36^{\prime} 28.2^{\prime \prime} \mathrm{E}, 1,080 \mathrm{~m}, 25.04 .2013$.

4. Central Serbia, Stolovi Mts, by town of Kraljevo, near Usovica peak, $43^{\circ} 37^{\prime} 36.1^{\prime \prime} \mathrm{N}, 20^{\circ}$ $35^{\prime} 48.8^{\prime \prime}$ E, 1,170 m, 25.04.2013.

5. Central Serbia, Stolovi Mts, by town of Kraljevo, $43^{\circ} 37^{\prime} 55.3^{\prime \prime}$ N, $20^{\circ} 37^{\prime} 53.8^{\prime \prime}$ E, 655 m, 25.04.2013.

6. Central Serbia, Stolovi Mts, by town of Kraljevo, $43^{\circ} 36^{\prime} 36.4^{\prime \prime} \mathrm{N}, 20^{\circ} 40^{\prime} 09.5^{\prime \prime} \mathrm{E}, 460 \mathrm{~m}$, 25.04.2013.

7. SW Serbia, Ibar gorge, between Ušće and Maglič castle, along the river Ibar, $43^{\circ} 30^{\prime} 45.5^{\prime \prime}$ $\mathrm{N}, 20^{\circ} 36^{\prime} 53.9^{\prime \prime}$ E, $330 \mathrm{~m}, 26.04 .2013$.

8. SW Serbia, Ibar gorge, between Ušće and Maglič castle, on the bank of the river Ibar, $43^{\circ}$ $33^{\prime} 27.3^{\prime \prime} \mathrm{N}, 20^{\circ} 37^{\prime} 07.0^{\prime \prime} \mathrm{E}, 320 \mathrm{~m}, 26.04 .2013$.

9. SW Serbia, Ibar gorge, bank of the river Ibar at Maglič castle, $43^{\circ} 36^{\prime} 40.4^{\prime \prime} \mathrm{N}, 20^{\circ} 33^{\prime} 12.3^{\prime \prime}$ E, $270 \mathrm{~m}, 26.04 .2013$.

10. Central Serbia, road side at Bogutovačka banja, $43^{\circ} 39^{\prime} 20.4^{\prime \prime} \mathrm{N}, 20^{\circ} 32^{\prime} 18.0^{\prime \prime} \mathrm{E}, 340 \mathrm{~m}$, 27.04.2013.

11. Central Serbia, along the road to Bogutovačka banja, $43^{\circ} 39^{\prime} 15.9^{\prime \prime} \mathrm{N}, 20^{\circ} 32^{\prime} 41.3^{\prime \prime}$ E, 255 $\mathrm{m}, 27.04 .2013$.

\section{RESULTS AND DISCUSSION}

A total of 126 bryophyte taxa (12 liverworts and 114 mosses) were collected in the Ibar gorge and its surroundings. The numerals following the species names refer to the collection sites described above.

\section{Hepaticae}

Barbilophozia barbata (Schreb.) Loeske - 1: serpentine grassland

Cephaloziella divaricata (Sm.) Schiffn. - 1, 4: serpentine grassland; 7: shaded serpentine rock

Frullania dilatata (L.) Dumort. - 1: serpentine grassland and bark of Fraxinus ornus; 3, 4: serpentine rock; 9: bark of Alnus; 11: Fraxinus bark

Lophocolea heterophylla (Schrad.) Dumort. - 3: decaying wood

Lophocolea minor Nees - 1: serpentine grassland and along a stream valley; 10: lime-containing schistose rock

Metzgeria conjugata Lindb. - 1: along a stream valley

Metzgeria furcata (L.) Dumort. - 1: along a stream valley; 3: serpentine rock

Pellia endiviifolia (Dicks.) Dumort. - 11: wet, lime-containing schistose rock

Plagiochila porelloides (Torrey ex Nees) Lindenb. - 1: along a stream valley

Radula complanata (L.) Dumort. - 3: serpentine rock; 7: shaded serpentine rock; 11: Fraxinus bark

Reboulia hemisphaerica (L.) Raddi - 1: serpentine grassland

Riccia sorocarpa Bisch. - 4: serpentine grassland 


\section{Musci}

Abietinella abietina (Hedw.) M. Fleisch. - 1: serpentine grassland; 6: serpentine rock at a stream; 10: lime-containing schistose rock

Amblystegium serpens (Hedw.) Schimp. - 1: serpentine grassland and along a stream valley; 7: shaded serpentine rock, bank of the river and bark of Acer campestre; 10, 11: limecontaining schistose rock

Anomodon attenuatus (Hedw.) Huebener - 7: bark of Acer campestre; 10: lime-containing schistose rock

Anomodon viticulosus (Hedw.) Hook. et Taylor - 1: serpentine grassland

Atrichum undulatum (Hedw.) P. Beauv. - 3: soil

Barbula convoluta Hedw. - 1: serpentine grassland; 10: wet, lime-containing schistose rock

Barbula unguiculata Hedw. - 1: serpentine grassland; 7, 9: bank of the river; 10: lime-containing schistose rock

Brachytheciastrum velutinum (Hedw.) Ignatov et Huttunen - 1: along a stream valley; 2: soil among serpentine rocks; 3 : decaying wood; 7 : shaded serpentine rock

Brachythecium albicans (Hedw.) Schimp. - 1: serpentine grassland

Brachythecium glareosum (Bruch ex Spruce) Schimp. - 10: lime-containing schistose rock

Brachythecium rivulare Schimp. - 1: along a stream valley

Brachythecium rutabulum (Hedw.) Schimp. - 3: decaying wood; 7, 9: bank of the river; 8: bank of the river and bark of Salix

Bryoerythrophyllum recurvirostrum (Hedw.) P. C. Chen - 1: serpentine grassland; 8: bark of Salix; 9: bark of Alnus

Bryum alpinum Huds. ex With. -1 , 4: serpentine grassland; 2: at a rivulet

Bryum argenteum Hedw. - 1: serpentine grassland; 7: shaded serpentine rock

Bryum caespiticium Hedw. - 1, 4: serpentine grassland; 10: lime-containing schistose rock

Bryum capillare Hedw. - 1: serpentine grassland; 3: decaying wood; 7: shaded serpentine rock

Bryum dichotomum Hedw. - 2, 4: soil among serpentine rocks

Bryum gemmiferum R. Wilczek et Demaret - 7, 9: bank of the river

Bryum moravicum Podp. - 2: soil among serpentine rocks; 7: shaded serpentine rock; 8: bark of Salix; 9: bark of Alnus; 10: lime-containing schistose rock

Bryum pallens Sw. ex anon. - 11: wet, lime-containing schistose rock

Bryum pseudotriquetrum (Hedw.) P. Gaertn. et al. - 1, 2: along a rivulet; 5, 6: serpentine rock at a stream

Bryum ruderale Crundw. et Nyholm - 4: serpentine grassland; 10: lime-containing schistose rock

Buxbaumia viridis (Moug. ex Lam. et DC.) Brid. ex Moug. et Nestl. - 3: decaying wood

Calliergonella cuspidata (Hedw.) Loeske - 9: bank of the river

Campylophyllum calcareum (Crundw. et Nyholm) Hedenäs - 1: serpentine grassland; 10: lime-containing schistose rock

Ceratodon purpureus (Hedw.) Brid. - 4: serpentine grassland; 7: shaded serpentine rock

Cinclidotus fontinaloides (Hedw.) P. Beauv. - 9: bank of the river

Cirriphyllum crassinervium (Taylor) Loeske et M. Fleisch. - 7: shaded serpentine rock

Cratoneuron filicinum (Hedw.) Spruce - 1, 7: along a rivulet; 5, 6: serpentine rock at a stream;

9: bank of the river; 11: wet, lime-containing schistose rock

Ctenidium molluscum (Hedw.) Mitt. - 3: serpentine rock

Dialytrichia mucronata (Brid.) Broth. - 8: bank of the river and bark of Salix

Dicranum scoparium Hedw. - 1: serpentine grassland

Didymodon fallax (Hedw.) R. H. Zander - 1: serpentine grassland 
Didymodon insulanus (De Not.) M. O. Hill - 1: serpentine grassland; 7: shaded serpentine rock; 11: lime-containing schistose rock

Didymodon luridus Hornsch. - 1: serpentine grassland; 8: bank of the river; 10: lime-containing schistose rock

Didymodon nicholsonii Culm. - 8: bank of the river

Didymodon rigidulus Hedw. - 10, 11: lime-containing schistose rock

Didymodon sinuosus (Mitt.) Delogne - 1: along a stream valley; 7: shaded serpentine rock and at a rivulet; 8: bank of the river and bark of Salix; 9: bank of the river

Didymodon tophaceus (Brid.) Lisa - 1: along a rivulet; 9: bank of the river; 10: wet, limecontaining schistose rock

Encalypta streptocarpa Hedw. - 1: serpentine grassland; 10: wet, lime-containing schistose rock; 11: lime-containing schistose rock

Encalypta vulgaris Hedw. - 1: serpentine grassland

Eucladium verticillatum (With.) Bruch et Schimp. - 10, 11: wet, lime-containing schistose rock

Fissidens crassipes Wilson ex Bruch et Schimp. - 7: at a rivulet

Fissidens dubius P. Beauv. - 1: along a stream valley; 2: soil among serpentine rocks; 3 : serpentine rock; 10: lime-containing schistose rock

Fissidens gracilifolius Brugg.-Nann. et Nyholm - 10: wet, lime-containing schistose rock

Funaria hygrometrica Hedw. - 1: serpentine grassland; 2: at a rivulet

Grimmia hartmanii Schimp. - 3: serpentine rock

Grimmia laevigata (Brid.) Brid. - 1: serpentine grassland

Grimmia lisae De Not. - 1, 4: serpentine grassland; 5: serpentine rock at a stream

Grimmia ovalis (Hedw.) Lindb. - 1: serpentine grassland

Grimmia pulvinata (Hedw.) Sm. - 1: serpentine grassland and bark of Juglans regia; 4: serpentine rock; 5: serpentine rock at a stream

Gymnostomum aeruginosum Sm. - 11: wet, lime-containing schistose rock

Gymnostomum viridulum Brid. - 10: wet, lime-containing schistose rock

Hedwigia ciliata (Hedw.) P. Beauv. - 1: serpentine grassland

Herzogiella seligeri (Brid.) Z. Iwats. - 2: soil among serpentine rocks; 3: decaying wood

Homalothecium sericeum (Hedw.) Schimp. - 1: serpentine grassland; 7: shaded serpentine rock; 11: lime-containing schistose rock

Homomallium incurvatum (Schrad. ex Brid.) Loeske - 7: shaded serpentine rock

Hygroamblystegium humile (P. Beauv.) Vanderp., Goffinet et Hedenäs - 7: bank of the river

Hygroamblystegium varium (Hedw.) Mönk. $-7,8$ : bank of the river

Hylocomium splendens (Hedw.) Schimp. - 1: serpentine grassland

Hypnum cupressiforme Hedw. var. cupressiforme - 1, 4: serpentine grassland; 2, 3: serpentine rock; 7: shaded serpentine rock and bark of Acer campestre; 10, 11: lime-containing schistose rock

Hypnum cupressiforme Hedw. var. lacunosum Brid. - 1: along a stream valley; 6: serpentine rock at a stream

Isothecium alopecuroides (Lam. ex Dubois) Isov. - 1: along a stream valley; 3: serpentine rock Leptodictyum riparium (Hedw.) Warnst. - 7: bank of the river

Leskea polycarpa Hedw. - 7: shaded serpentine rock, bank of the river and bark of Acer campestre; 8: bank of the river; 11: Fraxinus bark

Leucodon sciuroides (Hedw.) Schwägr. - 1: serpentine grassland; 7: shaded serpentine rock; 11: Fraxinus bark

Mnium lycopodioides Schwägr. - 7: bank of the river 
Mnium marginatum (Dicks.) P. Beauv. - 8: bank of the river and bark of Salix

Neckera besseri (Lobarz.) Jur. - 7: shaded serpentine rock

Orthotrichum affine Schrad. ex Brid. - 1: bark of Fraxinus ornus; 11: Fraxinus bark

Orthotrichum anomalum Hedw. - 1: serpentine grassland and bark of Juglans regia and Fraxinus ornus; 7 : shaded serpentine rock

Orthotrichum cupulatum Hoffm. ex Brid. var. riparium Huebener - 9: bank of the river

Orthotrichum diaphanum Schrad. ex Brid. - 1: bark of Juglans regia

Orthotrichum lyellii Hook. et Taylor - 11: Fraxinus bark

Orthotrichum obtusifolium Brid. - 11: Fraxinus bark

Orthotrichum pumilum Sw. ex anon. - 1: bark of Juglans regia and Fraxinus ornus

Orthotrichum striatum Hedw. - 1: bark of Fraxinus ornus; 11: Fraxinus bark

Oxyrrhynchium hians (Hedw.) Loeske - 1: along a stream valley; 8: bank of the river; 10: lime-containing schistose rock

Oxyrrhynchium pumilum (Wilson) Loeske - 7: at a rivulet

Phascum cuspidatum Hedw. - 1: serpentine grassland

Plagiomnium affine (Blandow ex Funck) T. J. Kop. - 1: along a stream valley

Plagiomnium cuspidatum (Hedw.) T. J. Kop. - 8: bark of Salix

Platygyrium repens (Brid.) Schimp. - 7: bark of Acer campestre

Platyhypnidium riparioides (Hedw.) Dixon -1, 7: along a rivulet; 8: bank of the river

Pleurochaete squarrosa (Brid.) Lindb. - 1: serpentine grassland

Polytrichastrum formosum (Hedw.) G. L. Sm. - 2: soil among serpentine rocks; 4: serpentine grassland

Polytrichum piliferum Hedw. - 7: shaded serpentine rock

Pseudocrossidium horschuchianum (Schultz) R. H. Zander - 1: serpentine grassland

Pseudoleskeella nervosa (Brid.) Nyholm - 1: serpentine grassland; 7: bark of Robinia pseudoacacia; 11: Fraxinus bark

Pseudoscleropodium purum (Hedw.) M. Fleisch. - 1: along a stream valley; 2: soil among serpentine rocks

Pterigynandrum filiforme Hedw. - 3: serpentine rock

Pylaisia polyantha (Hedw.) Schimp. - 1: serpentine grassland; 11: Fraxinus bark

Rhynchostegiella tenella (Dicks.) Limpr. - 10: wet, lime-containing schistose rock

Rhynchostegium confertum (Dicks.) Schimp. - 7: shaded serpentine rock

Rhynchostegium murale (Hedw.) Schimp. - 10: lime-containing schistose rock

Schistidium apocarpum (Hedw.) Bruch et Schimp. - 1: serpentine grassland; 3: serpentine rock; 10: lime-containing schistose rock

Schistidium crassipilum $\mathrm{H}$. H. Blom - 1: serpentine grassland; 10: lime-containing schistose rock

Schistidium papillosum Culm. - 5: serpentine rock at a stream

Sciuro-hypnum populeum (Hedw.) Ignatov et Huttunen - 3: serpentine rock; 8: bank of the river

Syntrichia latifolia (Bruch ex Hartm.) Huebener - 9: bark of Alnus

Syntrichia montana Nees - 1: serpentine grassland

Syntrichia papillosa (Wilson) Jur. - 1: bark of Juglans regia; 11: Fraxinus bark

Syntrichia ruralis (Hedw.) F. Weber et D. Mohr - 1: serpentine grassland

Syntrichia virescens (De Not.) Ochyra - 1: bark of Juglans regia

Taxiphyllum wissgrillii (Garov.) Wijk et Margad. - 7: at a rivulet

Thuidium assimile (Mitt.) A. Jaeger - 1: serpentine grassland and along a stream valley; 10: lime-containing schistose rock 
Tortella tortuosa (Hedw.) Limpr. - 1: serpentine grassland; 10: wet, lime-containing schistose rock; 11: lime-containing schistose rock

Tortula inermis (Brid.) Mont. - 1: serpentine grassland

Tortula muralis Hedw. - 1: serpentine grassland; 7: shaded serpentine rock; 10: lime-containing schistose rock

Tortula subulata Hedw. - 7: shaded serpentine rock; 10, 11: lime-containing schistose rock Weissia brachycarpa (Nees et Hornsch.) Jur. - 1: serpentine grassland; 2: soil among serpentine rocks; 10: lime-containing schistose rock

Weissia controversa Hedw. - 1: serpentine grassland and along a stream valley

Weissia longifolia Mitt. - 1: serpentine grassland; 2: soil among serpentine rocks

\section{Bryophyte vegetation and its nature conservation merit}

In the serpentine grasslands on slopes of the valley the occurrence of several sub-Mediterranean and Mediterranean elements are characteristic, e.g. Didymodon insulanus, D. luridus, Encalypta vulgaris, Grimmia laevigata, G. lisae, Pleurochaete squarrosa, Pseudocrossidium horschuchianum, Syntrichia montana, and Tortula inermis. Grimmia lisae has been recently reported for the first time in Serbia from this collection (Papp et al. 2016). It has a very large population in the grasslands at Maglič castle. Many common species of temperate zone of Europe are also abundant in the grasslands like Barbula species (B. convoluta, B. unguiculata), Bryum species (B. argenteum, B. caespiticium, B. capillare, B. dichotomum), Didymodon fallax, Grimmia pulvinata, Orthotrichum anomalum, Phascum cuspidatum, Syntrichia ruralis, and Weissia species (W. brachycarpa, W. controversa, W. longifolia).

Many sub-Mediterranean species occur in the riverbank of Ibar and along streams, rivulets flowing into the river, like Cinclidotus fontinaloides, Dialytrichia mucronata, Didymodon luridus, D. nicholsonii, D. sinuosus, Fissidens crassipes, Oxyrrhynchium pumilum. In spite of its southern distribution Dialytrichia mucronata is rare in most of the Balkan countries and it has been recently reported in Serbia from this collection (Papp et al. 2016). Didymodon nicholsonii is known only from Greece (Sabovljević et al. 2008) and it has been recently reported from Montenegro (Papp et al. 2014a) and Serbia (Papp et al. 2015). Oxyrrhynchium pumilum is red-listed as critically endangered (CR) in Romania (Ştefănuț and Goia 2012) and as endangered (EN) in Bulgaria (Natcheva 2015). In the Red data book of the Republic of Bulgaria (Natcheva 2015) only two known localities are mentioned from western Bulgaria, although several populations were reported from the Strandzha Mts (Papp et al. 2011). In Serbia it is known from Petnica region (Papp and Sabovljević 2001) and from the Djerdap National Park (Papp et al. 2006).

Another rare species in the Balkans, which is living in the riverbank, is Bryum gemmiferum, a southern sub-Atlantic element, known only from Roma- 
nia and Serbia. In both countries it is red-listed; critically endangered (CR) in Romania (Ştefănuț and Goia 2012), vulnerable (VU) in Serbia (Sabovljević et al. 2004).

Moreover, mainly common species of the temperate zone of Europe (e.g. Amblystegium serpens, Barbula unguiculata, Brachythecium rutabulum, Oxyrrhynchium hians) and temperate hygrophytes (like Bryum pseudotriquetrum, Calliergonella cuspidata, Cratoneuron filicinum, Didymodon tophaceus, Hygroamblystegium humile, H. varium, Leptodictyum riparium, Leskea polycarpa, Orthotrichum cupulatum var. cupulatum, and Platyhypnidium riparioides) predominate in the riverbank and along streams, rivulets. Hygroamblystegium humile is red-listed as vulnerable (VU) in Bulgaria (Ganeva 2015) and in Slovenia (Martinčič 1992). In Serbia it is known only from Petnica region (Papp and Sabovljević 2001) and from the Jerma gorge (E Serbia) (Papp and Erzberger 2009). Some boreal, subboreal species also appear, like Brachythecium rivulare, Mnium lycopodioides, M. marginatum, Plagiochila porelloides. Mnium lycopodioides is red-listed as vulnerable (VU) in Bulgaria (Natcheva 2015) and in Romania (Ştefănuț and Goia 2012).

On shaded serpentine rocks some sub-Mediterranean, sub-Atlantic elements also appear (e.g. Cirriphyllum crassinervium, Rhynchostegium confertum), but mainly species of the temperate zone of Europe are characteristic (e.g. Cephaloziella divaricata, Amblystegium serpens, Brachytheciastrum velutinum, Bryoerythrophyllum recurvirostrum, Bryum capillare, B. moravicum, Homalothecium sericeum, Hypnum cupressiforme, Leucodon sciuroides, Orthotrichum anomalum, Radula complanata) accompanied by some subboreal species, like Hedwigia ciliata, Homomallium incurvatum, Tortula subulata or subcontinental elements as Neckera besseri.

Trees in the river valley maintain rich epiphytic flora, mainly species of the temperate zone of Europe, like Frullania dilatata, Orthotrichum affine, O. anomalum, O. diaphanum, O. pumilum, Syntrichia virescens, S. papillosa. A rare species in the Balkans, Syntrichia latifolia, was found on the bark of Alnus in the riverbank. This is red-listed in Romania as vulnerable (VU) (Ştefănuț and Goia 2012) and in Bulgaria as critically endangered (CR), where only its two small populations are known (Ganeva 2015).

On wet, lime-containing schistose rocks at Bogutovačka banja calciphilous species were collected, like the boreal Bryum pallens, Gymnostomum aeruginosum, the Mediterranean Gymnostomum viridulum, the sub-Mediterranean, sub-Atlantic Eucladium verticillatum, Campylophyllum calcareum, and Rhynchostegiella tenella. Gymnostomum viridulum is rare in many Balkan countries and it has been recently reported in Serbia from this collection (Papp et al. 2016). On bark of old Fraxinus trees near Bogutovačka banja a red-listed (VU-vulnerable) species in Serbia (Sabovljević et al. 2004), the subcontinental Orthotri- 
chum obtusifolium was found accompanied by other sub-Mediterranean, subAtlantic Orthotrichum species (O. lyelii, O. striatum) and temperate elements as Frullania dilatata, Orthotrichum affine, Radula complanata and Syntrichia papillosa.

Above 1,000 m a.s.l. in the Stolovi Mts in Abieto-Fagetum forests a few boreal, subboreal species appear on decaying logs as Buxbaumia viridis, Herzogiella seligeri and on serpentine rocks Pterigynandrum filiforme, Grimmia hartmanii. Buxbaumia viridis is included in the Bern Convention and the European Union Habitats and Species Directives and vulnerable in Europe according to the Red data book of European bryophytes (ECCB 1995). Several extant populations are known in Serbia (Papp et al. 2009, 2014b) and in the neighbouring Balkan countries, such as Croatia (Papp et al. 2013a, b, Alegro et al. 2014), Montenegro (Dragićević et al. 2011), and the Republic of Macedonia (Papp and Erzberger 2012).

Besides of these, several common species of the temperate zone of Europe also occur; e.g. Brachytheciastrum velutinum, Brachythecium rutabulum, Bryum capillare, Lophocolea heterophylla on decaying wood, Ctenidium molluscum, Sciuro-hypnum populeum, Fissidens dubius, Frullania dilatata, Hypnum cupressiforme, Isothecium alopecurum, Metzgeria furcata, Radula complanata, Schistidium apocarpum on shaded, serpentine rocks.

Another Schistidium species rare in the Balkans, S. papillosum was collected from exposed serpentine rocks along a stream in the Stolovi Mts accompanied by Grimmia species (G. lisae, G. pulvinata).

\section{CONCLUSIONS}

The climate of the Ibar gorge can be characterised by quite strong Mediterranean influence, which in combination with specific dry bedrock is highly reflected in the bryophyte flora. Almost one fourth (24.3\%) of the bryophyte species found are Mediterranean, sub-Mediterranean, sub-Atlantic elements, although the predominance of species of temperate zone of Europe (50.2\%) is obvious. Sub-Mediterranean, Mediterranean elements are very abundant in the serpentine grasslands of the Ibar gorge and on the river bank. Several rare species in Serbia and in the Balkans can be found in these habitats and the adjoining valleys (e.g. Bryum gemmiferum, Dialytrichia mucronata, Didymodon nicholsonii, Gymnostomum viridulum, Hygroamblystegium humile, Orthotrichum obtusifolium, Syntrichia latifolia). Grimmia lisae has a very large population in the grasslands at Maglič and this is its only known locality in Serbia. At higher elevation in the Stolovi Mts boreal, subboreal species also appear. In a managed Abieto-Fagetum forest, the boreal Buxbaumia viridis, a species included in the Bern Convention and the European Union Habitats and Species Directives, was also found in spite of that the forest seemed to be quite dry. The 
boreal, subboreal leafy liverworts, which are usual accompanying species of $B$. viridis on decaying logs, were lacking; only the subboreal moss, Herzogiella seligeri and the temperate Lophocolea heterophylla occurred together with B. viridis. The species was rare on the spot, detected only on 2-3 logs. Another interesting finding in the Stolovi Mts is Schistidium papillosum, a rare species in the Balkans, collected from exposed serpentine rocks along a stream.

It can be summarised that the Ibar gorge maintains a unique bryophyte assemblage due to the serpentine bedrock and the continental, Mediterranean climatic influence.

Acknowledgement - The study was supported by the bilateral project of the Hungarian Academy of Sciences and the Serbian Academy of Sciences and Art (2013-2015) entitled "Investigations on cryptogam flora (bryophytes, lichens) and biodiversity in Serbia and Hungary, especially in the habitats of rare species".

\section{REFERENCES}

Alegro, A., Papp, B., Szurdoki, E., Šegota, V., Šapić, I. and Vukelić, J. (2014): Contributions to the bryophyte flora of Croatia III. Plitvička jezera National Park and adjacent areas. - Studia bot. hung. 45: 49-65. http://dx.doi.org/10.17110/StudBot.2014.45.49

Dragićević, S., Papp, B. and Erzberger, P. (2011): Distribution of Buxbaumia viridis (Moug. ex Lam. et DC.) Brid. ex Moug. et Nestl. (Bryophyta) in Montenegro. - Acta Bot. Croat. 71(2): 1-6. http://dx.doi.org/10.2478/v10184-011-0066-1

Düll, R. (1983): Distribution of the European and Macaronesian liverworts (Hepaticophytina). - Bryol. Beitr. 2: 1-115.

Düll, R. (1984): Distribution of the European and Macaronesian mosses (Bryophytina) I. Bryol. Beitr. 4: 1-109.

Düll, R. (1985): Distribution of the European and Macaronesian mosses (Bryophytina) II. Bryol. Beitr. 5: 110-232.

ECCB (1995): Red data book of European bryophytes. - European Committee for Conservation of Bryophytes, Trondheim, $291 \mathrm{pp}$.

Ganeva, A. (2015): Syntrichia latifolia, Leptodyctium humile. - In: Peev, D. (ed.): Red data book of the Republic of Bulgaria. 1. Plants and fungi. BAS and MoEW, Sofia, pp. 81, 124.

Grolle, R. and Long, D. G. (2000): An annotated check-list of the Hepaticae and Anthocerotae of Europe and Macaronesia. - J. Bryol. 22: 103-140. http://dx.doi.org/10.1179/ jbr.2000.22.2.103

Hill, M. O., Bell, N., Bruggeman-Nannenga, M. A., Brugués, M., Cano, M. J., Enroth, J., Flatberg, K. I., Frahm, J.-P., Gallego, M. T., Garilleti, R., Guerra, J., Hedenäs, L., Holyoak, D. T., Hyvönen, J., Ignatov, M. S., Lara, F., Mazimpaka, V., Muñoz, J. and Söderström, L. (2006): An annotated checklist of the mosses of Europe and Macaronesia. - J. Bryol. 28(3): 198-267. http://dx.doi.org/10.1179/174328206X119998

Marković, J. Đ. (1990): Enciklopedijski geografski leksikon Jugoslavije Svjetlost. - Sarajevo. 
Martinčič, A. (1992): Rdeci seznam ogroženih listnatih mahov (Musci) v Sloveniji. - Varstvo Narave 18: 1-190.

Mladenović, A. (2010): Geophysical model of the tertiary basin between Čačak and Kraljevo. Proceedings of the congress of the geologists of Serbia, pp. 669-673.

Natcheva, R. (2015): Eurhynchium pumilum, Mnium ambiguum. - In: Peev, D. (ed.): Red data book of the Republic of Bulgaria. 1. Plants and fungi. BAS and MoEW, Sofia, pp. 97, 126.

Papp, B. and Sabovljević, M. (2001): Contribution to the knowledge of the bryoflora of the region of Petnica (W Serbia, Yugoslavia). - Studia bot. hung. 32: 107-120.

Papp, B. and Erzberger, P. (2009): Contribution to the bryophyte flora of South-Eastern Serbia: Suva Planina Mts and its surroundings. - Studia bot. hung. 40: 125-142.

Papp, B. and Erzberger, P. (2012): Contribution to the bryophyte flora of the Former Yugoslav Republic of Macedonia (FYROM). - Polish Bot. J. 57(1): 205-221.

Papp, B., Erzberger, P. and Sabovljević, M. (2006): Contribution to the bryophyte flora of Djerdap National Park (E. Serbia). - Studia bot. hung. 37: 131-144.

Papp, B., Alegro, A., Šegota, V., Šapić, I. and Vukelić, J. (2013a): Contributions to the bryophyte flora of Croatia I. Gorski kotar Region (W Croatia). - Studia bot. hung. 44: 193-211.

Papp, B., Alegro, A., Šegota, V., Šapić, I. and Vukelić, J. (2013b): Contributions to the bryophyte flora of Croatia II. The northern Velebit. - Studia bot. hung. 44: 213-228.

Papp, B., Dragićević, S. and Erzberger, P. (2014a): Contributions to the bryophyte flora of the Komovi Mts (Montenegro). - Studia bot. hung. 45: 17-31. http://dx.doi.org/10.17110/ StudBot.2014.45.17

Papp, B., Erzberger, P. and Sabovljević, M. (2009): European red-listed bryophyte species collected during the expeditions of the Hungarian Natural History Museum in Serbia between 2000-2006. - In: Ivanova, D. (ed.): Plant, fungal and habitat diversity investigation and conservation. Proceedings of IV Balkan Botanical Congress, Sofia, 20-26 June 2006. Institute of Botany, Sofia, pp. 541-546.

Papp, B. Natcheva, R. and Ganeva, A. (2011): The bryophyte flora of Northern Mt Strandzha. - Phytol. Balcan. 17(1): 21-32.

Papp, B., Szurdoki, E., Pantović, J. and Sabovljević, M. (2014b): Contributions to the bryophyte flora of the Pešter plateau, SW Serbia. - Studia bot. hung. 45: 33-47. http:// dx.doi.org/10.17110/StudBot.2014.45.33

Papp, B., Pantović, J., Sabovljević, M. and Szurdoki, E. (2014c): Myurella sibirica, a moss species new to Montenegro and Serbia: its range extension towards south-eastern Europe. - Cryptogamie, Bryol. 35(3): 321-326. http://dx.doi.org/10.7872/cryb.v35. iss3.2014.321

Papp, B., Pantović, J., Sabovljević, M. and Szurdoki, E. (2014d): Interesting and new species for the bryophyte flora of Serbia. - Herzogia 27(1): 221-225. http://dx.doi.org/10.13158/ heia.27.1.2014.221

Papp, B., Szurdoki, E. and Sabovljević, M. (2014e): Bryum canariense (Brid.) Bruch. \& Schimp. [Serbia]. In: Ellis, L. T. (ed.): New national and regional bryophyte records 40. - J. Bryol. 36(3): 224. http://dx.doi.org/10.1179/1743282014Y.0000000115

Papp, B., Szurdoki, E. and Sabovljević, M. (2015): Didymodon nicholsonii Culm. [Serbia]. In: Ellis, L. T. (ed.): New national and regional bryophyte records, 44. - J. Bryol. 37(3): 228-241. http://dx.doi.org/10.1179/1743282015Y.0000000014 
Papp, B., Szurdoki, E., Pantović, J. and Sabovljević, M. (2016): New records of Mediterranean/Atlantic mosses in the flora of Serbia. - Herzogia 29(1): 185-189. http://dx.doi. org/10.13158/heia.29.1.2016.185

Ros, R. M., Mazimpaka, V., Abou-Salama, U., Aleffi, M., Blockeel, T. L., Brugués, M., Cano, M. J., Cros, R. M., Dia, M. G., Dirkse, G. M., El Saadawi, W., Erdağ, A., Ganeva, A., González-Mancebo, J. M., Herrnstadt, I., Khalil, K., Kürschner, H., Lanfranco, E., Losada-Lima, A., Refai, M. S., Rodrígez-Nuñez, S., Sabovljević, M., Cérgio, C., Shabbara, H., Sim-Sim, M. and Söderström, L. (2007): Hepatics and Anthocerotes of the Mediterranean, an annotated checklist. - Cryptogamie, Bryol. 28(4): 351-437.

Ros, R. M., Mazimpaka, V., Abou-Salama, U., Aleffi, M., Blockeel, T. L., Brugués, M., Cros, R. M., Dia, M. G., Dirkse, G. M., Draper, I., El Saadawi, W., Erdağ, A., Ganeva, A., Gabriel, R., González-Mancebo, J. M., Granger, C., Herrnstadt, I., Hugonnot,V., Khalil, K., Kürschner, H., Losada-Lima, A., Luís, L., Mifsud, S., Privitera, M., Puglisi, M., Sabovljević, M., Sérgio, C., Shabbara, H. M., Sim-Sim, M., Sotiaux, A., Tacchi, R., Vanderpoorten, A. and Werner, O. (2013): Mosses of the Mediterranean, an annotated checklist. - Cryptog. Bryol. 34(2): 99-283. http://dx.doi.org/doi/ 10.782/cryb. v34.iss2.2013.99

Sabovljević, M. (2000): Checklist of hepatics of the Federal Republic of Yugoslavia. - Lindbergia 25: 37-42.

Sabovljević, M. and Natcheva, R. (2006): A check-list of the liverworts and hornworts of Southeast Europe. - Phytol. Balcan. 12: 169-180.

Sabovljević, M. and Stevanović, V. (1999): Moss conspectus of Federal Republic of Yugoslavia. - Fl. Medit. 9: 65-95.

Sabovljević, M., Cvetić, T. and Stevanović, V. (2004): Bryophyte red list of Serbia and Montenegro. - Biodiversity and Conservation 13: 1781-1790. http://dx.doi.org/10.1023/ B:BIOC.0000029338.97776.66

Sabovljević, M., Natcheva, R., Tsakiri, E., Dihoru, G., Dragićević, S., Erdağ, A. and Papp, B. (2008): Check-list of the mosses of SE Europe. - Phytol. Balcan. 14: 207-244.

Smith, A. J. E. (2004): The moss flora of Britain and Ireland. - University Press, Cambridge, $739 \mathrm{pp}$.

Ştefănuț, S. and Goia, I. (2012): Checklist and red list of the bryophytes of Romania. - Nova Hedwigia 95(1-2): 59-104. http://dx.doi.org/10.1127/0029-5035/2012/0044 
